\title{
The Strategies to Develop Bilingual Ability for Vietnamese
}

\author{
Tran Thi Thanh Dieu \\ Faculty of English Linguistics and Literature, University of Social Sciences and Humanities, Viet Nam National University, Ho Chí Minh \\ City, Vietnam
}

Email address:

thdieu2003@yahoo.com, thanhdieutt@hcmussh.edu.vn

\section{To cite this article:}

Tran Thi Thanh Dieu. The Strategies to Develop Bilingual Ability for Vietnamese. International Journal of Language and Linguistics. Vol. 6, No. 2, 2018, pp. 36-50. doi: 10.11648/j.ij11.20180602.12

Received: February 11, 2018; Accepted: March 26, 2018; Published: March 30, 2018

\begin{abstract}
The hypothesis is that non-native language speakers (e.g., Vietnamese who study English) face lots of difficulties due to the differences in linguistic features and negative transference. Therefore, no one can deny that it is not easy to study a language and more difficult to study a second language or a foreign language now that every language in the world has its own characteristics which are nearly completely different from one another. To solve this problem, many linguists have created their theories of second language acquisition, such as Behaviorist's theory, Nativist's theory, Interactionist's theory, Information Processing theory, Vygotsky's theory, Halliday's theory, Sociolinguistic's theory. Therefore, with the hope to solve those problems, this study focuses on some difficulties facing learners of English and their solutions. The article is divided into 3 main parts, including difficulties in the four skills as (1) speaking and listening for communication such as prosody and fluency; (2) writing and (3) reading. About the solutions for the difficulties mentioned above, to begin with, in prosody, solution focuses on the importance of combining phonological knowledge with rhythm, melody, English stress rules and syntax rules in teaching and learning English intonation affected by stress for Vietnamese students, verified by Experimental Phonetics. Moreover, writing, grammar and vocabularies improving as well as identification of the types of writing can be considered as one of the practical solutions. Last but not least, in reading, K-W-L strategy (K: KNOWN, W: WHAT, L: LEARNT), one the best ways to activate schemata is also the suitable solutions as well.
\end{abstract}

Keywords: English Rhythmic Patterns, Melody, Phonetic Experiment, Schemata, Interview, Questionnaire

\section{Introduction}

Language is a system of interrelated terms, the underlying code which ensures that people can speak and understand each other [21]. It has social underpinning and is an operative system embedded in brain of everyone who has learnt a given language. This system is a network of relationships which characterized as being of the two kinds: "syntagmatic" (i.e. items are arranged in the consecutive, linear order) and associative, later termed "paradigmatic" (i.e. the organization of units in a deeper fashion dealing with grammatical and semantic relations) [22]. In addition, language is emphasized as a system of (arbitrary signs and the central part of overall science of sign relations or semiotics (following CS. Peirce's terminology). In the other words, language is a system of recourse (consisting of first, the simultaneous lexicogrammar (words and grammar) which has three aspects consisting of transitivity (things, even, circumstance, mood (structure, elements, theme-rheme, cohesion) and second, the generic structure of text) to make the three simultaneous meaning (consisting of idealtional-representing experience and logic as well as interpersonal-exchanging information and goods-and-services, expressing position and textualorganising the flow of information) in context. Therefore, language comprises both form and meaning that must be focused on the same level [23].

As a result, not only vocabularies but also grammar must be paid much attention to when learning a language, especially a foreign language. In Vietnam, no foreign language is widely used so Vietnamese quite naturally have few opportunities to use or to improve a second language (but in Vietnam they are all foreign languages), as well as they hardly have purpose for learning unless they are in special jobs or situations where they have to meet foreigners. Therefore, learners of foreign languages in Vietnam face lots of difficulties, especially learners of ESP. As a result, the time has come when a research should be carried out to find 
out the difficulties facing Vietnamese learners of foreign languages, detailed in the topic "The lecturers and students' ability and method to acquire the foreign languages", with the scope is limited in Vietnam National University HCMC Vietnam, from which "The strategies to develop the bilingual ability for Vietnamese in the multi-lingual communicative context have been systemized", as the permission of carrying out the research from the University of Social Sciences and Humanities - Vietnam National University, written in the following decision document:

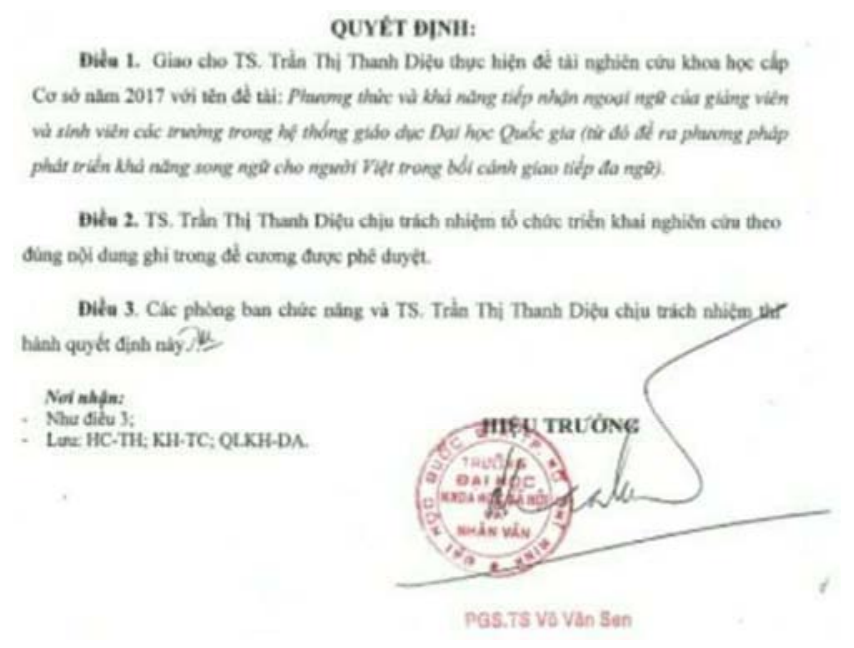

Figure 1. Written dicision to allow the research done.

The topic has been developed through the phonetic experimental research into prosody, especially English prosody, which has been considered as the most difficult in learning English; as well as the survey research through the collection of experiences in learning and teaching foreign languages, as well as difficulties facing students and lecturers, by the questionnaires and questions for interviewing lecturers and students in Vietnam National University. Moreover, the improvement of lesson plans, the solutions for the problems facing learners have been also systemized. In the end, some improved teaching methods have been raised for consideration.

However, something that should be mentioned is all the questionnaires and interview questions have been created in Vietnamese language through Google forms for distance investigation, which is suitable for the time and the ways the Vietnamese interviewers participate in the survey. Therefore, since the research was carried in Vietnamese context, the questionnaires have been written in Vietnamese for Vietnamese students to answer the questions now that bilingual questionnaires or interview questions faces something relating to the respected field. As a result, the questions written in Vietnamese are the best choice which adapts all aspects.

\section{Methodology}

\subsection{Pilot Study}

The pilot study of the interview and questionnaire was carried out with the lecturrers and students in the Vietnam National University. The lecturrers and students who participated in the pilot study were also foreign language teachers and students at English and non-English department.

The methods used in the stress and intonation research are the comparative strategy based on the prosodic analysis of Rhythmic patterns between English and Vietnamese, as well as the combination of quantitative approach and phonetic experimental approach to find out students' stress as well as intonation mistakes and the solutions. The word samples for stress research were recorded from the 'Oxford Advanced Learner Dictionary' 'Cambridge Advanced Learner Dictionary' and 'Multi-Dictionary version 9.0 Huy Biên 2008', called standard pronunciation (Cách phát âm chuẩn = CPAC) or RP (Received pronunciation) and from the population (students), called investigating samples (Mẫu khảo sát $=\mathrm{MKS})$ or $\mathrm{T}$ (Token). In addition, the sentence sample for intonation research were recorded from the $C D$ ROM of the Cambridge Book for Cambridge Exam Examination paper from University of Cambridge ESOL Examination - IELTS 5 - Cambridge University Press, called standard pronunciation: RP (Received/ Standard pronunciation, called CPAC in Vietnamese) and from the population (students), called investigating samples ( $\mathrm{T}$ (Token: investigated samples, called MKS in Vietnamese). The data was analyzed and illustrated by SPEECH ANALYZER (Copyright (C) 1996-2007 by SIL International) and PRAAT 5.05.12. (copyright @ 1992-2008 by Paul Boersma and David Weenink).

\subsection{Procedure \& Research Schedule}

The questionnaires and Interview questions were sent randomly to the lecturers and the students in the Vietnam National University via email, Google forms and direct interview. The time for the research to be carried out is from January 2010 to February 2018

Table 1. Reaearch Schedule.

\begin{tabular}{|c|c|c|}
\hline Time & What to do (Action) (Step) & Findings - Result \\
\hline & Research into prosody: & \\
\hline & English prosody to find out intonation mistakes made by & A case study of solutions to some intonation mistakes made by \\
\hline $1 / 2010-1 /$ & Vietnamese students & Vietnamese students - A phonetic experimental research. International \\
\hline 2015 & $\begin{array}{l}\text { Comparison between English and Vietnamese prosody to } \\
\text { find out the solutions for intonation mistakes to improve } \\
\text { speaking and listening skills }\end{array}$ & $\begin{array}{l}\text { Journal of Language and Linguistics USA - ISSN 2330-0221 - 2015; } 3 \\
\text { (2) }\end{array}$ \\
\hline $1 / 2010-1 /$ & Research into second language acquisition & A Some Vietnamese Viewpoints upon Second Language Acquisition \\
\hline 2015 & Summary of second language acquisition theory & Theories in Language Contact Environment. International Journal of \\
\hline
\end{tabular}




\begin{tabular}{|c|c|c|}
\hline Time & What to do (Action) (Step) & Findings - Result \\
\hline & $\begin{array}{l}\text { Vietnamese viewpoints on second language acquisition } \\
\text { theories }\end{array}$ & Language and Linguistics USA - ISSN 2330-0221 - 2015; 5 (2) \\
\hline $\begin{array}{l}1 / 2010-1 / \\
2015\end{array}$ & $\begin{array}{l}\text { Research into teaching methodology } \\
\text { Schemata activating skill } \\
\text { Trying a suitable strategy (KWL strategy) to teach reading } \\
\text { comprehension }\end{array}$ & $\begin{array}{l}\text { Trying K-W-L Strategy on Teaching Reading Comprehension to Passive } \\
\text { Students in Vietnam. International Journal of Language and Linguistics } \\
\text { USA - ISSN 2330-0221 - 2016; } 1 \text { (2) }\end{array}$ \\
\hline $\begin{array}{l}1 / 2010-1 / \\
2018\end{array}$ & $\begin{array}{l}\text { Research into prosody: } \\
\text { English prosody to find out stress mistakes made by } \\
\text { Vietnamese students } \\
\text { Comparison between English and Vietnamese prosody to } \\
\text { find out the solutions for stress mistakes to improve } \\
\text { speaking and listening skills }\end{array}$ & $\begin{array}{l}\text { 1. Some English Stress Mistakes and Solutions - A Phonetic } \\
\text { Experimental Research on Vietnamese Students, International Journal of } \\
\text { Language and Linguistics USA - ISSN 2330-0221 - 2017; } 3 \text { (2) } \\
\text { 2. Hiện tượng liên ngữ tiếng Anh ở sinh viên người Việt. Tạp chí Tự điển } \\
\text { học và Bách Khoa Thư - ISSN 1859-3135 - Số } 3 \text { (17), tháng } 5 \text { - } 2012 \\
\text { 3. Phonetic experimental research into the acquisition of English stress } \\
\text { through rhythm by Vietnamese students. Tạp chí Khoa học Công Nghệ } \\
\text { Giao thông Vận tải - ĐHGTVT TP.HCM - ISSN 0866-7020 - Số 2-04/ } \\
2012 \\
\text { 4. Cách xác định trợg âm từ tiếng Anh đối với sinh viên Việt Nam. Tạp } \\
\text { chí Ngôn ngứ Đời ô̂ng - ISSN 0868-3409 - Số } 6 \text { - 06/ 2012 } \\
\text { 5. Kiểm chứng phương pháp nhận diện vị trí trọng âm từ tiếng Anh bằng } \\
\text { ngữ âm học thực nghiệm. Tạp chí Đại học Thủ Dầu Một - ISSN 1859- } \\
4433 \text { - Số 02 (5)/2012 }\end{array}$ \\
\hline $\begin{array}{l}1 / 2016-10 / \\
2017\end{array}$ & $\begin{array}{l}\text { Research into the lecturers and students' ability and method } \\
\text { to acquire the foreign language in Vietnam National } \\
\text { University HCMC } \\
\text { Design the questionnaires, interview questions } \\
\text { Send the Google form links of questionnaires to the lectures } \\
\text { and students } \\
\text { Collect the evidence of lecturers and students' foreign } \\
\text { language ability } \\
\text { Data Analysis } \\
\text { Using all the research results }\end{array}$ & Having conclusion \\
\hline $\begin{array}{l}10 / / 2016-2 / \\
2018\end{array}$ & $\begin{array}{l}\text { To systemize the strategies to develop the bilingual ability } \\
\text { for Vietnamese in the multi-lingual communicative context. } \\
\text { Science publication on international journal }\end{array}$ & $\begin{array}{l}\text { Submitting the article to the International Journal of Language and } \\
\text { Linguistics - USA }\end{array}$ \\
\hline
\end{tabular}

\subsection{Survey Research}

Using the survey research with the function of:

(1). Opinion survey to uncover the opinion and attitudes of the participant about specific issues such as a new teaching method used, teaching ways of the lecturer using KWL strategy for teaching reading comprehension, ...

(2). Evaluation survey to identify the lecturers and students' ability and method to acquire the foreign language in Vietnam National University HCMC, from which the strategies to develop the bilingual ability for Vietnamese in the multilingual communicative context were systemized.. Therefore, the questions were developed to find out what lecturers and students think about their teaching and learning program goal or objectives of a particular language program as well as about its tests, materials, teaching, administration, the difficulties facing learners of foreign language, lecturers' teaching method, and learners' foreign language study experience... (2). Judgment survey to obtain the view of participants (only samples). Students were asked to judge the effectiveness of a language program's objectives and materials in terms of how useful or difficult they are, how necessary to future language use especially to passive students with the purpose of encouraging them to be more active in improving foreign language skills, as well as how they were to learn. Students were simply providing their judgment.

-Questionnaire (self-administered and group administered questionnaire), to collect the lecturers and students' thinking of the subjects in their studying program, the ways of teaching, learning and testing. This type of survey is so efficient for gathering information on a large scale and also questionnaires to collect colleagues' opinions after observing the class.

Self-administered: used questionnaire for this class and Group administered questionnaire: used for the other classes.

Self- administered Questionnaire used by mailing out the Google form links and filled out by participants in their own home (i.e., they are self-administered to make sure that they were not influenced by any factors such as teacher or classmate attention, as well as they have enough time for careful answers.

Group administered questionnaire which is administered to participants while they are in class or at meeting. This type can solve the problem caused by the Self - administered Questionnaire: They often have very low return rate and they must be completely self explanatory because further clarification is not possible. Moreover, by using this type, the students were captive audiences and felt obliged to fill out the questionnaire (giving a high return rate), as well as lecturers could be present to explain any ambiguities as they arise and knew exactly what conditions existed when questionnaires were filled out.

Steps in Survey project

1. Stating the construct.

2. Specifying survey objectives and research question: 
Specifying survey objective: to collect the students' attitudes towards teaching and learning method and find out difficulties facing learners and lecturers of English as well as their experiences.

3. Selecting question format.

4. Selecting statistic analysis.

5. Writing survey questions.

6. Asking panel of expert.

7. Asking students to review the items.

\subsection{Research Questions}

1. What are the foreign language acquisition methods and ability of University lecturers and students in Vietnam National University HCMC?

2. What are the strategies to develop the bilingual ability for Vietnamese in the multi-lingual communicative contexts?

\subsection{Instrument Used to Collect Data of the Experiment}

\subsubsection{A lesson Planning Reflection Sheet}

This sheet can be involved in the Lesson plan with the purpose of reflection-on-action after the lesson has occurred to examine the particular aspect of the lesson, which have just been taught, have been handled. This lesson planning reflection sheets were completed after very lesson to evaluate how the transitions between activities were handled.

\subsubsection{Two Tests}

Two tests were used to test for all the population, the students in control groups and the students in experimental groups in the research into checking the KLW strategy used for improving reading comprehension.

1. Multiple-choice was used because it was objective and reliable as well as easy to score and easy to administer to large populations.

2. Story-frame (Cloze Test) is also very suitable to check reading comprehension skill..

\subsubsection{Colleagues' Observation and Criticizing}

Colleagues' observation and criticizing were used for only some control groups and Experimental group to let some other groups act naturally without other surveys) in the KWL research. Ask some colleagues to attend the class to observe, then some of them reported what they observed and some of them filled the questionnaire or checked against the class observation checklist.

\subsubsection{Sample Words for Stress rule Phonetic Experiment}

The sample words chosen to illustrate the stress rule phonetic experiment consist of: 6 multi-syllabic simple word of 3 word classes: Noun, Verb, Adjective: photo ['fəutəu] "bức ảnh", comfort ['kımfət] "tiện lợi", character ['kæriktə] “cá tính", entertain [entə 'tein] "giải trí", mimosa [mı'məusə] "hoa mimoza", chorale [kp "ra:l] "bản thánh ca"; and 3 complex words: photography [fəu 'togrəfi] "bức ảnh", confortable ['kımfətəbl] "tiện lợi", replenish [ri 'plenif] "bổ sung"; as well as 5 compound words: girl-friend "bạn gái", bad-tempered "nóng tính", second-class "hạng thứ hai", North-East "đông bắc", down-load "tải xuống"

\subsubsection{Sample Sentences for Intonation Rule Phonetic Expiriment}

A number of sentences for all the structural types of sentences consisting of Simple, compound, complex sentences were chosen for intonation phonetic experiment, as follows:

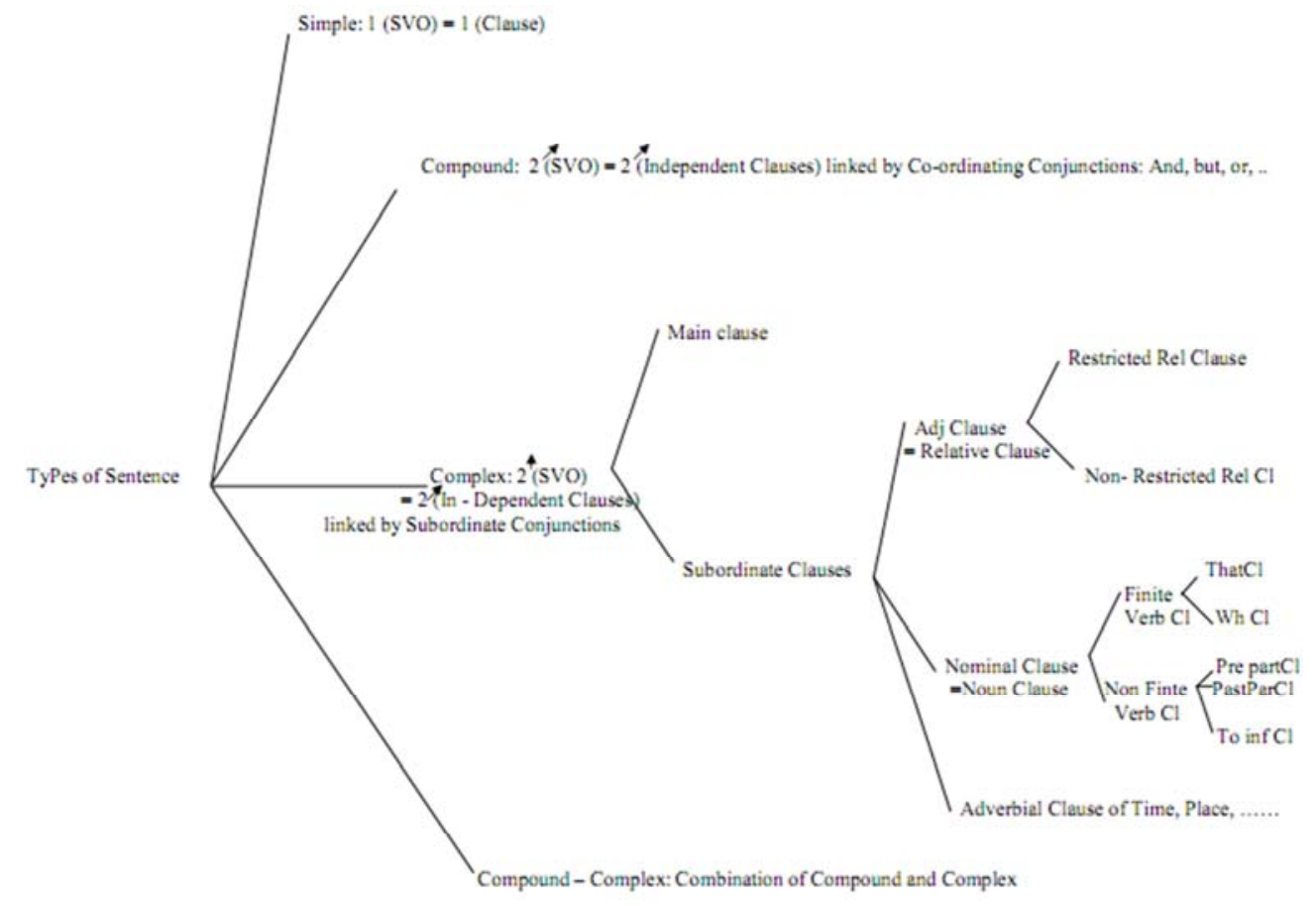


All the sentences used in the research were analyzed as the following tree diagram for the phonetic experiment in the intonation field.

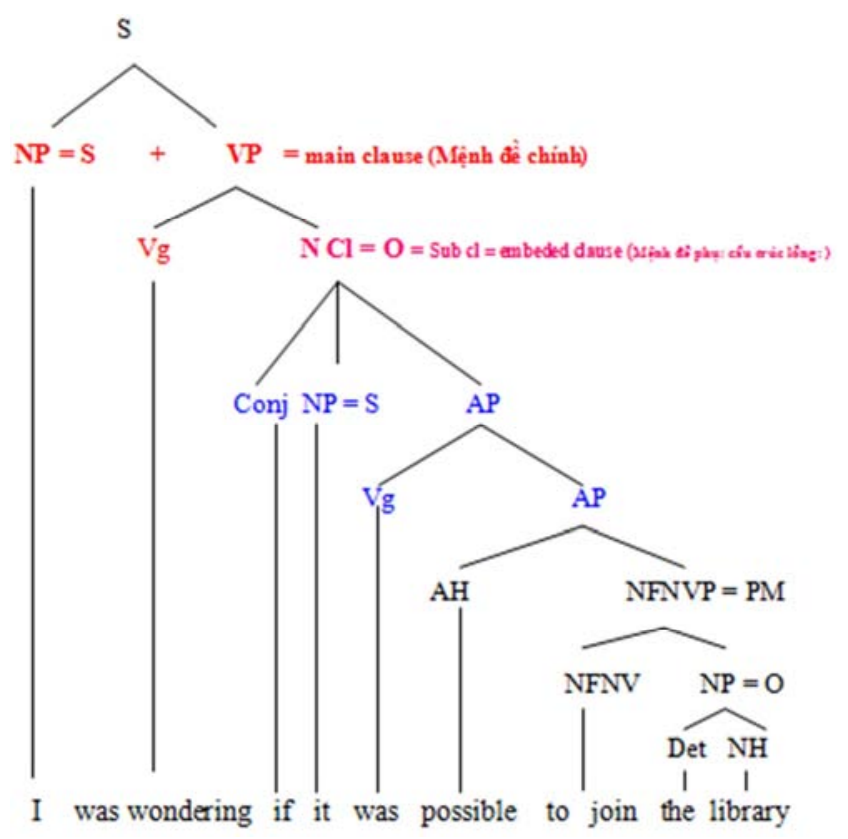

Figure 3. Tree diagram analysis of an intonation pattern.

\subsubsection{Filled Questionnaire and Interview}

Filled questionnaire was used to find out the students' thinking of the KWL strategy and if there was any change in their attitude towards reading class. Moreover, questionnaires and interview questions were used to collect the difficulties facing learners and lecturers of foreign languages as well as their experiences of their teaching and learning their foreign languages. However, something seeming to be a little limit is that all the questionnaires and interview questions have been created through Google forms for distance investigation, which is suitable for the time and the ways the Vietnamese interviewers participate in the survey. Therefore, since the research was carried in Vietnamese context, the questionnaire written in Vietnamese for Vietnamese students to answer the questions now that bilingual questionnaires or interview questions faces something relating to the respected field. As a result, the followings are the best choice which adapts all aspects.

1. Questionnaire for foreign language lecturers

https://docs.google.com/forms/d/e/1FAIpQLSfwR_B_io8p zM6C23q7pSkenvdNdzg_0cjuVX0F8YbiiyJo-

$\mathrm{g} /$ viewform? $\mathrm{c}=0 \& \mathrm{w}=1$

2. Questionnaire for foreign language students

https://docs.google.com/forms/d/e/1FAIpQLSffFyVe5nsoC SUV9s-

mNgPLzQEFO00FpdhENkakVD6Z651fwQ/viewform

3. Questionnaire for ESP students

https://docs.google.com/forms/d/e/1FAIpQLSdyNnBr241Ia R65V8VKbAJH5JZp1fIsPX1Q-

GxfcL1ilL6y5g/viewform?c=0\&w=1\&usp=mail_form_link

4. Interview questions
https://docs.google.com/forms/d/e/1FAIpQLSe0iJvSL1Qn RQ6bCtUQqRBRr41smMuuPgfKOe33-

suMoohCgw/viewform

Since the research was carried out in Vietnam, for Vietnamese lecturers and learners, the questionnaires and interview questions have been written in Vietnamese.

\section{Findings}

From data analysis of the research, the lecturers and students in Vietnam National University HCMC have good ability to acquire the foreign languages to adapt the requirement from the University for working and graduating. Moreover, some lecturers are good at a foreign language enough to go abroad for teaching and researching. Therefore, all of them have their all method to acquire their foreign languages such as English, French, ... However, they also face some following popular difficulties, from which the suitable strategies have been systemized to solve their problems for developing the bilingual ability for Vietnamese in the multi-lingual communicative context, briefly classified as difficulties in the four skills: speaking - listening, reading and writing, as follows:

\subsection{Difficulties in Speaking - Listening and the Solutions}

\subsubsection{Stress}

\section{Types of stress mistake}

From the questionnaire result, the most difficulty facing learners is stress level identification for speaking and listening as the following chart

\section{× O SV-Chuyên Ngoại Ngữ - ... D :}

\section{Bạn thấy điểm nào khó nhất trong phần Trọng âm (tiếng nước ngoài) ?}

122 câu trả lời

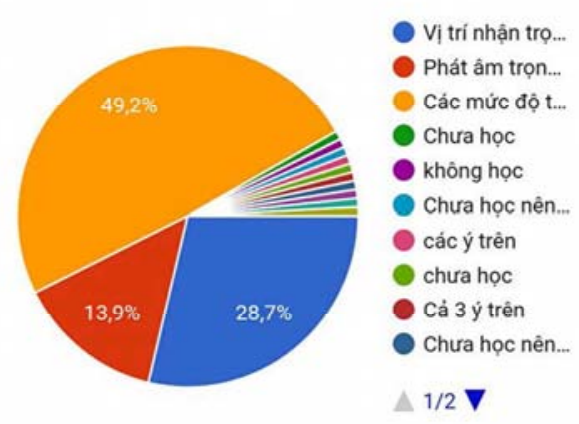

Figure 4. The difficulties face learners of stress. 
Therefore, from the phonetic experiment illustrated in the article "Some stress mistakes and solutions, a phonetic experimental research on Vietnamese students." [11] by Dr. Tran Thi Thanh Dieu, three types of English stress mistakes have been recognized

Type 1: Rhythmic error (A): Right stress placement but nearly the same force for the two syllables, no Rhythmic
Pattern $\{\mathrm{F}=[\mathrm{S} \mathrm{W}]\}$.

Type 2: Wrong placement of stress (B): Stress is placed at the wrong position to make the intensity peak pronounced by the standard pronunciation (Cách phát âm chuẩn $=\mathrm{CPAC}$ ) or RP (Received pronunciation) be different from the pronunciation of the population (students), called investigating samples (Mẫu khảo sát $=\mathrm{MKS})$, illustrated in the picture below:

\section{ĐóI CHIÉU HIẸU SÓ CƯỜNG Đọ 2 ĐINH ẢM TIÉT GIỮA CPAC VÀ MKS 1, 10}

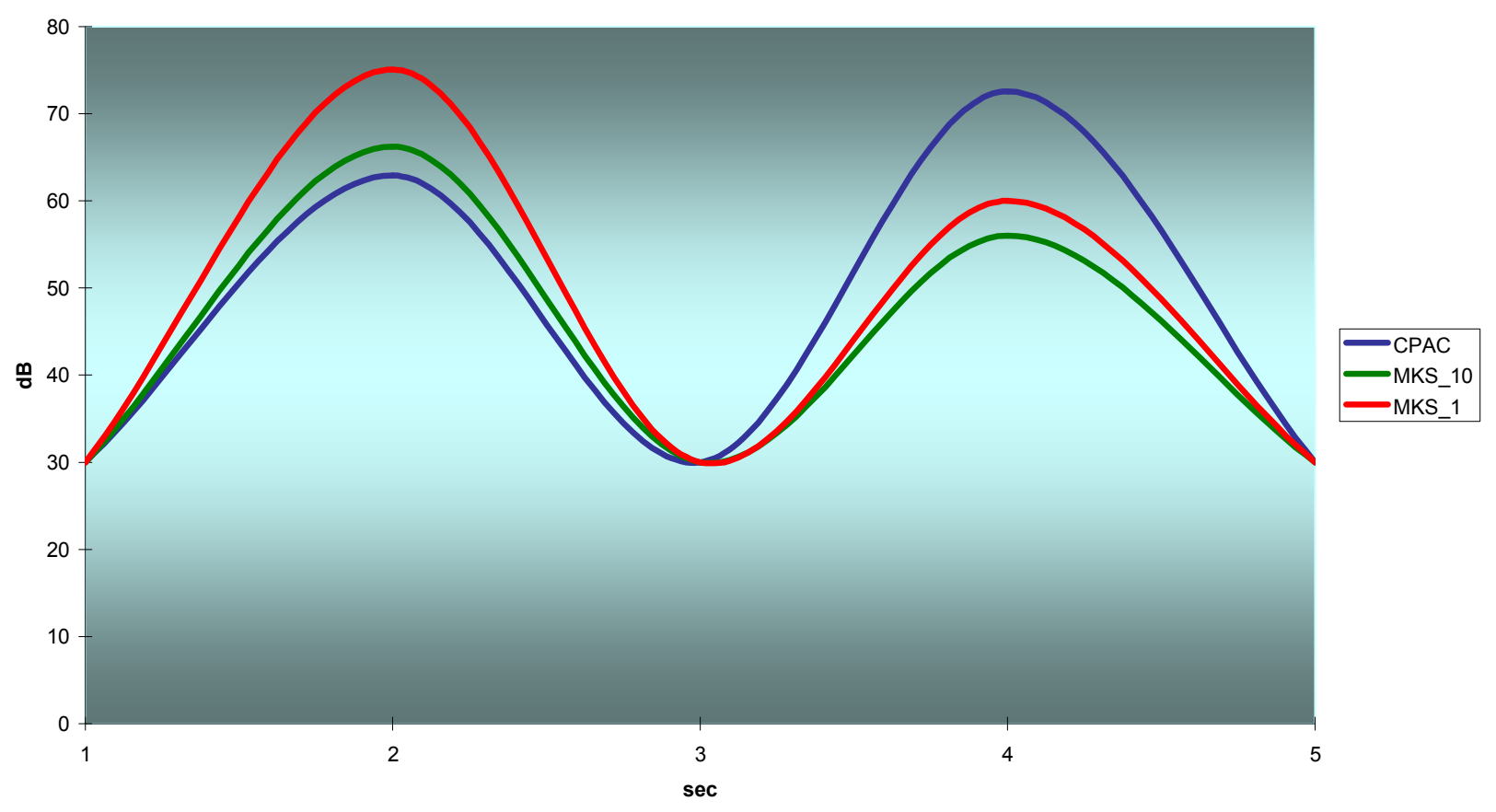

Figure 5. The difference between the two intensity peaks.

Type 3: The combination of type 1 and type $2:(A+B)$ : Rhythmic error (A) and Wrong placement of stress (B).

\section{Solutions}

Comparison between English and Vietnamese Rhythmic Patterns

"English is a Stress-timed language, with the rhythmic pattern based on the regular repetition of the stressed syllables. Whereas, Vietnamese tends to have the equal syllable to form the Rhythmic pattern of the Syllable-timed language, with the syllables having the equal intensity" [[3]]. Therefore in the paper "Some stress mistakes and solutions, a phonetic experimental research on Vietnamese students" by Dr. Tran Thi Thanh Dieu, a table of comparison between the English and Vietnamese rhythmic patterns has been summarized as follows [[11]].

Table 2. Comparison of the English and Vietnamese Rhythmic Patterns.

\begin{tabular}{lll}
\hline & English Rhythmic Pattern & Vietnamese Rhythmic Pattern \\
\hline Type of language & Stress-timed language, with the rhythmic pattern based & Syllable-timed language, with the syllables having the \\
on the regular repetition of the stressed syllables & equal intensity, \\
Meaning of the abreviation & $\{\mathrm{F}=[\mathrm{S} \mathrm{W}]\}$ & $\{\mathrm{N}=[\mathrm{A}]\}$ \\
& $F=$ Foot $=$ Bộ, $S=$ strong $=$ mạnh $W=$ weak $=$ yếu & $N=$ nhịp, $A=$ âm tiết \\
\hline
\end{tabular}

The article "Some stress mistakes and solutions, a phonetic experimental research on Vietnamese students." [11] also reveals that precisely, Vietnamese rhythmic pattern does not have the differences in intensity between stressed and unstressed syllables; on the contrary, English rhythmic pattern has differences in intensity (of course also in pitch and vowel duration). As a result, to be affected by this mother-tongue characteristics, Vietnamese students are not aware of the importance of syllable weight, shown through intensity, the main cue to identify English word stress, which decide the ability to catch the accurate information based on the main syllable of a word, which is not only the stressed syllable but also the tonic syllable in a tone unit. Therefore, teachers should spend more time training students how to count the number of syllable in a word, identify the syllable weight (strong syllable/ heavy syllable $=$ stressed syllable and weak syllable/ light syllable $=$ unstressed syllable) to be able to follow the English rhythmic pattern. Therefore, from the conclusion above, the English stress rules for English multi-syllabic words, are systemized, as follows [40]. 
Therefore, a brief summary of key points for recognizing the places of stress in English words has been consolidated based on rhythm, melody, word types (simple, compound, complex) word class, and the number of syllable with or without affix, as well as syllable structure based on the Rhythmic patterns. [37]. The foundation of English rhythmic patterns is the existence of the 2 types of syllables: light syllable and heavy syllable, called Trochee: Trochee: Trochaic foot with 1 long syllable $(=$ heavy syllable $=$ strong syllable $=$ stressed syllable) and 1 short syllable (= light syllable $=$ unstressed syllable). Strong syllable is a syllable with initial consonant and a complicated rhyme which consists of final consonant and a short vowel or long vowel or a diphthong as nuclei $[37$, p. 125]. On the contrary, a light syllable contains a vowel in the rhyme, with or without onset but no coda, as the first syllable in the word report, about [37, p. 85].

As a result, based on the distinction between heavy syllable and light syllable, word class, and the number of syllable with or without affix, as well as syllable structure based on the Rhythmic patterns, the characteristics of stressed and unstressed syllable have been simply systemized as follows: [40], p. $119-124]$.
1. The main characteristics of the unstressed syllable: Syllable containing schwa or short vowel or diphthong /ov/, ending with not more than 1 consonant.

2. The main characteristics of the stressed syllable: the syllable containing long vowel or diphthong or ending with more than 1 consonant.

3. Especially, no initial syllable in a three syllabic verb and no final syllable in a three syllabic noun and adjective, as well as no prefix are stressed.

1. Simple words: Multi-syllabic words without affix

a/. Simple disyllabic words: Syllable containing long vowel or diphthong or ending with more than 1 consonant is stressed. Ex: photo ['fəutəu], chorale [kp 'ra:l], comfort ['kAmfət].

b/. Simple trisyllabic words, with some special points

1. Trisyllabic verb: No initial syllable is stressed. Therefore, syllable containing long vowel or diphthong or ending with more than 1 consonant is stressed. Ex: entertain /[entə 'tein].

2. Trisyllabic noun: No final syllable is stressed. Therefore, the syllable containing long vowel or diphthong or ending with more than 1 consonant is stressed. Ex: character ['kærrktə], mimosa [mı'məusə].

Table 3. The main characteristics of the stressed and unstressed syllables in simple words.

\begin{tabular}{|c|c|c|c|}
\hline No & Unstressed syllable & Situation & Stressed \\
\hline 1 & Syllables containing schwa (ә I U) & \multirow{10}{*}{$\begin{array}{l}\text { The second syllable in the } 2 \text { syllabic noun } \\
\text { The middle syllable in the } 3 \text { syllabic noun } \\
\text { The final syllable in the } 3 \text { syllabic noun } \\
\text { The second syllable in the } 2 \text { syllabic noun and } \\
\text { Verb } \\
\text { Position in word } \\
\text { The second syllable in the } 2 \text { syllabic Adj and Verb } \\
\text { The final syllable in the } 3 \text { syllabic Verb } \\
\text { Situation } \\
\text { The final syllable in the } 3 \text { syllabic Adj and Noun } \\
\text { The second syllable in the } 2 \text { syllabic Verb } \\
\text { The second syllable in the } 2 \text { syllabic Adj }\end{array}$} & \multirow{4}{*}{$\begin{array}{l}\text { Initial } \\
\text { Syllable }\end{array}$} \\
\hline 2 & Syllables containing schwa end with not more than 1 consonant & & \\
\hline 3 & Syllables containing short vowel, or schwa, or diphthong /əu/ & & \\
\hline 4 & Syllables containing schwa or diphthong /əu/, end with not more than 1 consonant & & \\
\hline \multicolumn{2}{|c|}{ Stressed syllable } & & \\
\hline 1 & Syllables containing long vowel or diphthong or end with more than 1 consonant & & \\
\hline \multicolumn{2}{|c|}{ Exception: Unstress syllable } & & Stressed \\
\hline 1 & yllables containing long vowel or diphthong or end with more than 1 consonant & & \\
\hline & Syllables containing schwa or diphthong/əu/, end with 2 consonants & & \\
\hline 3 & Syllables end with more than 1 consonant & & \\
\hline
\end{tabular}

2. Complex word: Multi-syllabic word with affix

a. Prefix:

- There is no prefix of one or two syllables that always carries primary stress.

- Stress in the word with prefix is governed by the same rules as those for words without prefixes.

- Word-class pairs: The stress will be placed on the second syllable of the verb but on the first syllable of the noun or Adj.

b. Suffix:

1/. Suffixes carrying primary stress themselves: (-ain, -ee, - eer, -ese, -ette, -esque, -ique). Ex: entertain /entə 'tein/;

2/. Suffixes that do not affect stress placement: ('-able','age', '-al', '-en','-fu', '-ing').

3/. The stress on the syllable immediately preceding the suffix:

('ish'‘-like','-less','-ly','-ment'.'-ness','-ous','-fy','wisw','-y')

4/. Suffixes that influence stress in the stem: ('-eous', 'graphy', '-ial', '-ic', '-ion', '-ious', '-ty')

Table 4. The stress characteristics of prefix.

\begin{tabular}{llll}
\hline No & PREFIX: The stress characteristiecs of prefix & Brief \\
\hline 1 & There is no prefix of one or two syllables that always carries primary stress & Prefix iss unstressed \\
2 & Stress in the word with prefix is governed by the same rules as those for word without prefixes & Prefix does not affect sressed syllable & Verb æb 'strækt \\
3 & Word-class pairs & Prefix + 'Root & 'Prefix + Root \\
Ex: 'abstract' & 'æbstrækt & Adj & \\
\hline
\end{tabular}


Table 5. The stress characteristics of suffix.

\begin{tabular}{lll}
\hline No & SUFFIX: The stress characteristiecs of suffix & Suffix \\
\hline 1 & Suffixes carying primary stress themselves & '-ain', '-ee', '-eer', '-ese', '-ette', '-esque', '-ique' \\
2 & Suffixes that do not affect stress palcement & '-able','-age','-al','-en','-ful','-ing' \\
3 & the stress on the syllable immediately preceding the suffix & 'ish''-like','-less,',-ly','-ment','-ness','-ous','-fy','-wisw','-y' \\
\hline
\end{tabular}

3. Compound word: with 2 roots

In the Compound with 2 Nouns, The 1st syllable is Stress. In the other cases, the 2 nd syllable is stressed.

Table 6. Characteristics of the stressed syllable in compound words.

\begin{tabular}{ll}
\hline No & Stressed syllable \\
\hline 1 & The $1^{\text {st }}$ syllable is stressed: Compound with 2 Nouns \\
2 & The $2^{\text {nd }}$ syllable is stressed: The other cases \\
\hline
\end{tabular}

In short, English word stress can be recognized by the following criteria:

a/. Syllable structure characteristics: Only strong syllables are stressed. Strong syllables (sometimes called heavy syllable) is a syllable which has a complex rhyme, with two cases. First, a heavy syllable may have a short vowel, but one or more coda consonants. Second, it may have a branching nucleus, consisting of a long vowel or diphthong; such a syllable will be heavy whether it also has a bled coda;

b/. Word structure: Simple words are based on the syllable structure characteristics to recognize stress. Complex words: no prefix is stressed; Suffixes are stressed and unstressed, change stressed syllable or not. Compound words with 2 nouns are stressed on the first syllable; otherwise, the second syllable is stressed;

c/. Rhythmic pattern Stress-timed language, with the rhythmic pattern based on the regular repetition of the stressed syllables: Pattern $\{\mathrm{F}=[\mathrm{S} \mathrm{W}]\},(\mathrm{F}=$ Foot, $\mathrm{S}=$ strong, $\mathrm{W}=$ weak);

d/. Intensity: English word stress can be mainly recognized by intensity; therefore, stressed syllable is pronounced with much force (inténity), also longer (duration), and higher (pitch).

Remembering the four criteria above helps students prevent from the three main types of stress errors: (1). Rhythmic error (no Rhythmic Pattern $\{\mathrm{F}=[\mathrm{S} \mathrm{W}]\}$ ); (2). Stress placement error; and (3). The combination of Rhythmic and Placement error.

\subsubsection{Intonation}

\section{Types of intonation mistake}

Since the research was carried in Vietnamese context, the questionnaire was written in Vietnamese for Vietnamese students to answer the questions. Moreover, according to the research result titled "A case study of solutions to some intonation mistakes made by Vietnamese students - A phonetics experimental research"” [10], by Dr. Trần Thị Thanh Diệu, in general, we have discovered that $50 \%$ students found difficult in analyzing intonation patterns, which has serious influence on not only speaking but also listening, illustrated in the pie chart below,

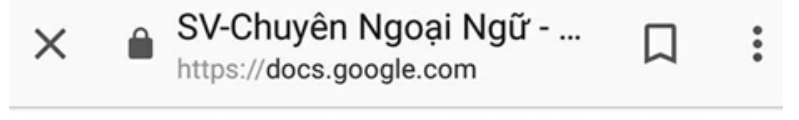

\section{Bạn thấy điểm nào khó nhất trong phần Ngữ điệu (tiếng nước ngoài)?}

\section{2 câu trả lời}
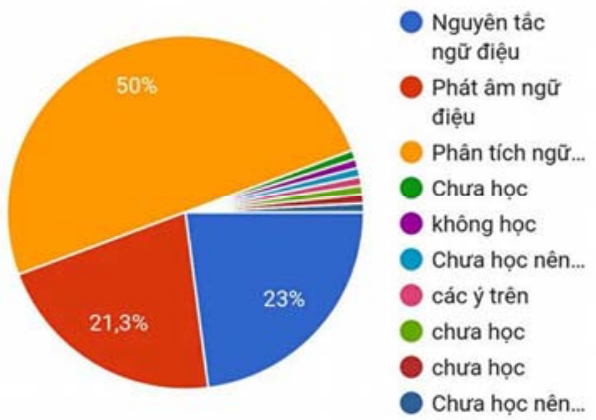

Figure 6. The difficulties face learners of intonation.

Intonation patterns can be divided into seven types of English intonation mistake when Vietnamese students pronounce a fragment/ tone unit.

Type 1: Mistake of rhythmic pattern (A). Even though students identify stress on the right syllable, pronounce each syllable with equal force to make the intensity difference between the peak of 2 or 3, 4 the syllables zero, or just a minor difference.

Type 2: Mistake of tonic syllable identification $(\mathrm{B})=$ not stress on the tonic syllable. Students place stress on the wrong syllable.

Type 3: Mistake of rhythm and tonic syllable identification $(\mathrm{A}+\mathrm{B}) /$ Students neither place stress on right syllable nor adapt the rhythmical pattern S_W (S: Strong, W: weak).

Type 4: Mistake of intonation pattern (C). Students make wrong pitch contour due to being unable to identify the intonation pattern in which this kind of sentence should be pronounced with raising or lowing voice.

Type 5: Mistake of rhythmic and intonation pattern (A $+C)$. Students neither adapt the rhythmic patterns nor intonation patterns.

Type 6: Mistake of tonic syllable identification and intonation pattern $(B+C)$. Students neither stress on the tonic syllable of a tone unit nor adapt the intonation patterns

Type 7: Mistake of rhythm, tonic syllable identification and intonation pattern $(\mathrm{A}+\mathrm{B}+\mathrm{C})$. 


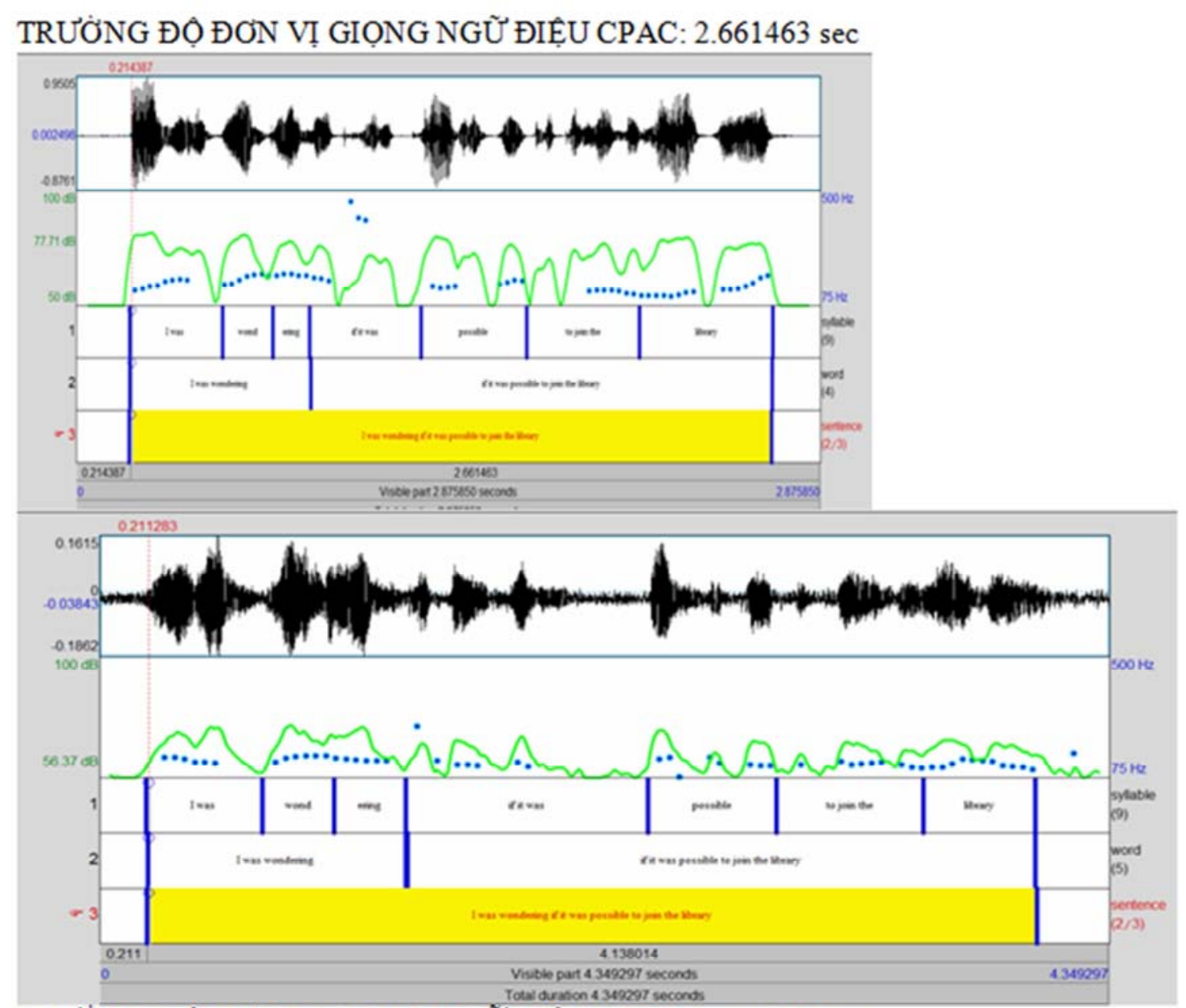

TRƯđ̛́NG ĐỘ ĐƠN VỊ GIỌNG NGƯ ĐIẸU MKS_18: 4.138014 sc

Figure 7. The difficulties facing learners of intonation; phonetic experiment for the tone unit "I was wondering if it is possible to join the library.

The combination of the three types of mistake: rhythmical pattern (A), tonic syllable identification (B) and intonation pattern (C): students place stress on the wrong syllable, can not pronounce with rhythm (the intensity difference between the peaks of 2 or 3, 4 the syllables are zero, or just a minor difference) and make the wrong pitch contour as well as the wrong duration.

\section{Solutions}

In real life, the speaker's use intonation, the rise and fall of the pitch of the voice, to convey sarcasm or resignation, anger or apprehension, or any of scores of other moods. Therefore, the work looks at both accent (pitch shift that points up individual words) and overall configurations (melodies that shape the meaning of whole sentences). The pitch of the voice plays the most important part. The pitch is described in terms of high and low. It shows that most easily understood utterances employ one or another of a surprisingly small stock of basic melodies, and it shows both intonation and visible gesture to be parts of a larger complex that conveys grammatical as well as emotional information [3].

As a result, intonation helps us to understand a speaker's feelings, a speaker's attitude, whether a speaker is asking us a question, whether a speaker is done and it's our turn to say something. Therefore, when pronouncing intonation, speakers must pay attention to the melody, illustrated by the pitch contour based on the intonation rules illustrated in the table of Intonation list below to adapt to English language.

Table 7. Intonation list.

\begin{tabular}{lll}
\hline No & Case & Intonation pattern \\
\hline 1 & Complete, definite statement & Fall \\
2 & Wh-question & Fall \\
3 & Yes-No question & Rise \\
4 & Alternative question (OR question) & Rise - fall \\
5 & Question tag & Fall-fall: certain, expect agreement \\
& & Fall-rise: not certain, asking for information \\
6 & Echo question & Rise \\
\hline
\end{tabular}




\begin{tabular}{|c|c|c|}
\hline No & Case & Intonation pattern \\
\hline \multirow{4}{*}{7} & \multirow{4}{*}{ Correcting } & - to query what the other person said, ask fot futher explanation \\
\hline & & - because not hear or understand or believe what wa said \\
\hline & & Fall on the correct word, to emphasise it \\
\hline & & Fall and rise in the in the incorrect information then Fall on the correct information, to emphasise it \\
\hline 8 & Listing & $\begin{array}{l}\text { Rise on each item of the list until the final one, where it fall } \\
\text { Use when begin a conversation }\end{array}$ \\
\hline 9 & Polite rise & $\begin{array}{l}\text { Use when answer the phone } \\
\text { (because the rise sound is less definite than a fall) }\end{array}$ \\
\hline 10 & Yes, no short answer & Fall-fall \\
\hline 11 & $\begin{array}{l}\text { Subordinate clause } \\
\text { Non-final phrase }\end{array}$ & Rise \\
\hline 12 & Main clause & Fall \\
\hline 13 & $\begin{array}{l}\text { Statement implying but } \ldots \\
\text { Ex: the weahter } \backslash \text { is good/ (but every } \\
\text { thing wlse was awful) }\end{array}$ & $\begin{array}{l}\text { Fall -rise } \\
\text { (- Fall marks the important information, } \\
\text { - rise implies that though the speaker may have made a posivetive statement, he is going to qualify it) }\end{array}$ \\
\hline
\end{tabular}

\subsubsection{Fluency}

Thinking in Vietnamese and translating into a foreign languages such as English in communication as in the illustrating chart below, is a popular mistake facing learners. This way makes the conversation become more slowly.

\section{$\times \quad \begin{aligned} & \text { SV-Chuyên Ngoại Ngữ } \\ & \text { https://docs.google.com }\end{aligned}$ khó nhất khi học Nói tiếng nước ngoài}

\section{2 câu trả lời}

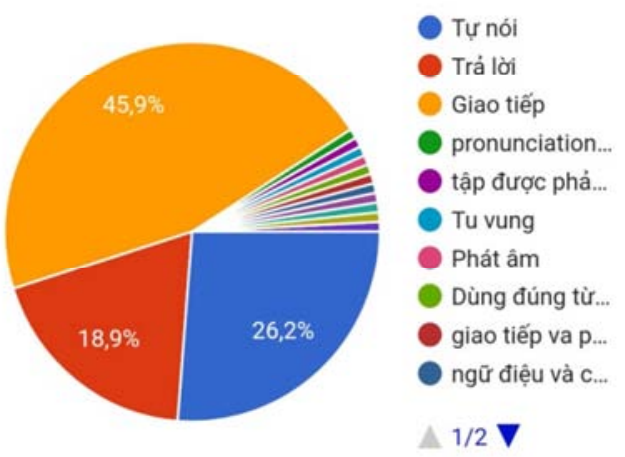

Figure 8. The difficulties face learners of speaking - listening.

\section{Solutions}

The useful way is practicing thinking in English. To practice thinking in English, learners should go to the speaking club. However, it is not enough. To write diary is also a good way but writing is a little different from speaking, especially the fluency. Therefore, one more way to improve fluency is trying to think in English about daily activities, anything happening every minute. Although this action makes the learners so tired, practice and practice so many times, for so long term, can help them be accustom to and therefore the tiredness will decrease, as well as the fluency will increase.
Moreover, not only intensive but also extensive listening practice plays important role in improving listening skill, from which listening and note taking is somewhat a vexed question. To solve this problem, note-taking outline is very necessary for some first steps practising. However, the ability of remembering, speaking, writing, which can be trained to gain success, is more important to help learners be able to choose and take note the most important and necessary points for further note-taking, understanding and answering the questions, .... In short, even though speaking and listening are the two separate subjects to practice, they are the two relating sides which can support each other in improving learners' ability and gaining success in communication. Last but not least, in speaking and listening, grammar also plays an important role for understanding and replying, as it has put by Dr. Bùi Hải Đăng, an English lecturer and director of the Administration section in the University of Social Sciences and Humanities - Vietnam National University "speaking-listening skills should be taught by helping students have careful preparation of not only vocabularies but also structures".

\subsection{Difficulties in Reading and the Solutions}

Types of reading mistakes

When reading a text, or practice reading comprehension skill, the difficulties facing readers are grammar and vocabularies, in which vocabularies makes the reading process slower so much since vocabularies seem to be waste too much time of readers. The survey conducted in this research reveals that $65.6 \%$ students found the most difficulty facing learners of reading comprehension was guessing the meaning from the context due to lacking of background knowledge relating to the text content. As it put by Vice Prof. Trương Văn Vỹ, the Dean of Faculty of Italian Linguistics and Literature - University of Social Sciences and Humanities - VNU, "his success in the second foreign language he has studied is due to his background knowledge of the first foreign language, and so on with his third, fourth foreign language ...." 


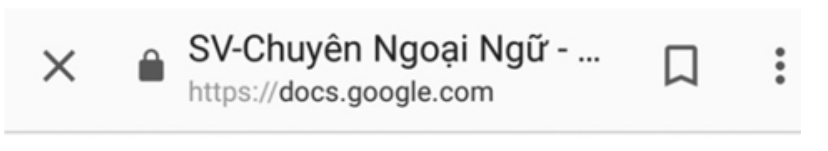

\section{Bạn thấy điểm nào khó nhất trong khi học đọc hiểu tiếng nước ngoài?}

122 câu trả lời

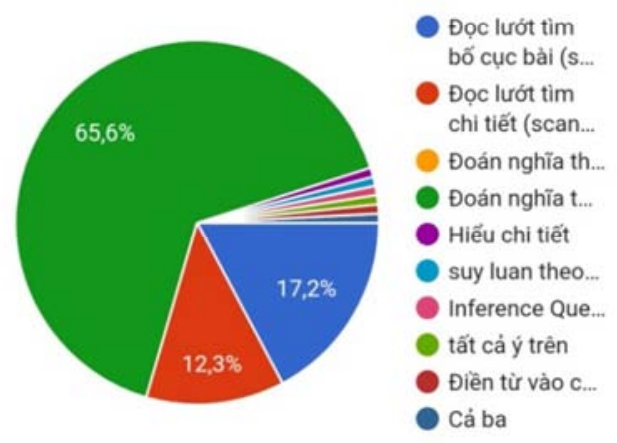

Figure 9. The difficulties facing learners of reading.

To solve this problem, there are two strategies which seem to be some of the most necessary.

Solutions

First, prior knowledge should be considered as one of the suitable solutions. According to Anderson's research, prior knowledge is extremely important in influencing how the reading text be interpreted. To read well, the knowledge which have already exitted about the topic must be accessed or made appropriately available so that comprehension can occur (Anderson and Pichert, 1987; Bransford, 1983) [20]. Therefore, to activate background knowledge before beginning reading the text, a K-W-L strategy should be used. $\mathrm{KWL}$ is a thinking-reading process, with three steps: $\mathrm{K}$ (What we know), W (What we want to find out, and L (What we learned and still need to learn). This procedure can help learners to access the knowledge they already have about the topic or make it available appropriately so that comprehension can occur: the first step: K: What they know and then discuss or think to find out what they want to know: $\mathrm{W}$ and last, after studying the text, they have to summarize what they learned and approach further to what they need to learn more (extra-knowledge): L.

In the other words, almost learners have a problem with guessing the meaning of the words from the contexts in which linguistic context refers to the linguistic environment where a word is used within a text; while situational context involves background knowledge of the readers, the situation in which the text has been written, the situation in which the story happened. Therefore, to guess the meaning from context, readers can base on the meaning of vocabulary items that surrounds it; the way the word is formed; background knowledge of the subject and the situation. As a result, the word relation, the structure relation, the part of speech, the word form are the important factors leading to successful guessing meaning of words based on the contexts.

\subsection{Difficulties in Writing and the Solutions}

\section{Types of writing mistake}

The popular problems are identifying wrong types of writing, writing ungrammatically, writing incoherently and lacking of vocabularies, as well as combination of these mistakes.

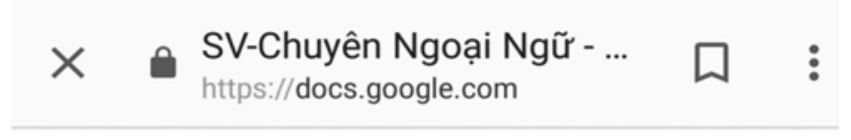

\section{Bạn thấy điểm nào khó nhất trong khi học Viết tiếng nước ngoài \\ 122 câu trả lời}
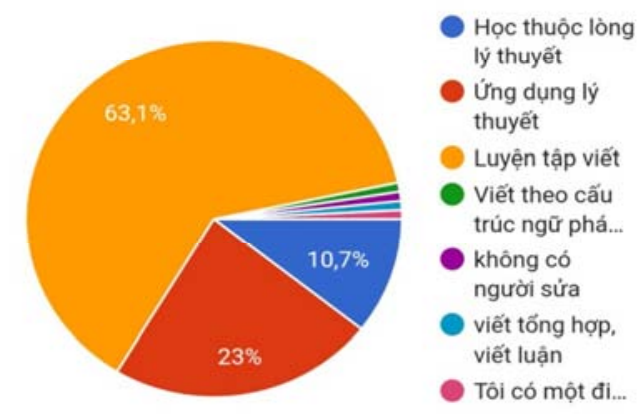

Figure 10. The difficulties face learners of writing.

\section{Solutions}

Types of writing: Help students to distinguish among the ways to develop a narrative, argumentative, cause-effect .... paragraphs/ essays. "Students find difficult in creating opinion and teachers should help students to think of the opinion of a piece of writing" said Dr. Le Hoang Dung, the dean of the Faculty of English Linguistics and Literature University of Social Sciences and Humanities - VNU. However, since the teachers can not go along with their students forever, based on the theory of writing, one of the best ways to help student create the opinions for writing is to teach them the way to develop the different types of writing, such as the way to develop an argumentative essay is different from a cause - effect essay. Moreover, the first but not least is to teach students how to develop a paragraph which consists of a topic sentences, some supporting sentences such as explanation, statistics, proverb for proving, or illustration and ended with a concluding sentence. Therefore, the students can think of what they have to write, 
which is their opinion.

Grammar: Try to master the grammar rules by studying in a class for grammar, read as many grammar books as possible and do grammar exercises of all grammar points.

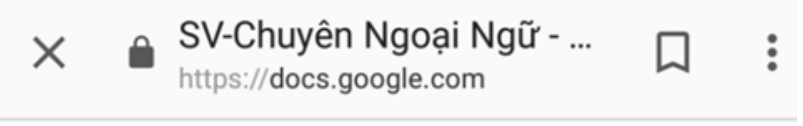

\section{Bạn thấy điểm nào khó nhất khi học Ngữ pháp tiếng nước ngoài?}

\section{2 câu trả lời}
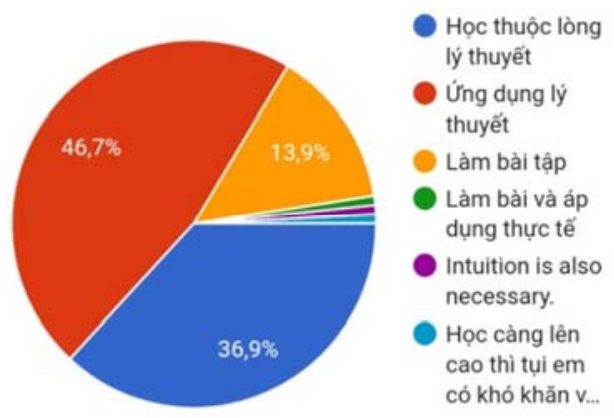

Figure 11. The difficulties face learners of grammar.

The survey conducted in this research reveals that $46.7 \%$ students found the most difficulty facing learners of grammar was applying the theories to do the exercises, to real life. One of the reasons is that students do not remember the grammar rules, the theories. Therefore, learning by heart grammar structure is also necessary as being said by Dr. Trần Thanh Nguyện, a very experienced linguist, "what is in our mind is ours". In addition, when doing the reading comprehension, pay much attention to the grammar points used in the reading texts to understand grammar used in real contexts.

Vocabularies: to have enough words for a piece of writing, students should pay attention to the following ways: (1) Accumulating vocabularies from the reading texts. (2) Accumulating vocabularies from preparing for writing. (3) Accumulating vocabularies from preparing for speaking topic. (4) Making plan to cumulate vocabularies, as follows: In the first week, learning by heart 10 words every day, after the first week, review 70 words. Then do the same with the 2nd week. After 4 weeks, spend 1 week reviewing 280 words cumulated in the 1 st month. And then do the same with the 2nd month. And then review after 3 months, and so on. Someone can think that we will forget all the words we have studied; it is true but the plan of cumulating word above is a phase with the two processes: 'learning process' and 'acquisition process'. What have been done is the 'learning process', a more conscious process, in which existing a subconscious process called 'acquisition process'. About the result of learning process, something logical is found in the Imput hypothesis of Nativist philosophy [14]. Comprehensible input must be $i+1, i+2 . i+3 \ldots$ Because " $i "$ is something like prior or background knowledge, without $" \ldots+1, \ldots+2 \ldots "$ no progress happen. This comprehensible enables acquisition and then output created (speaking, writing) is the result of and also the contribution to acquisition (comprehensible output) providing opportunities for Hypothesis testing that help learners confirm or reject their ideas about the language. This Output Hypothesis of Merill Swain gives a step to make the learning process become a circle with the main and last goal is acquisition the language, as follows:

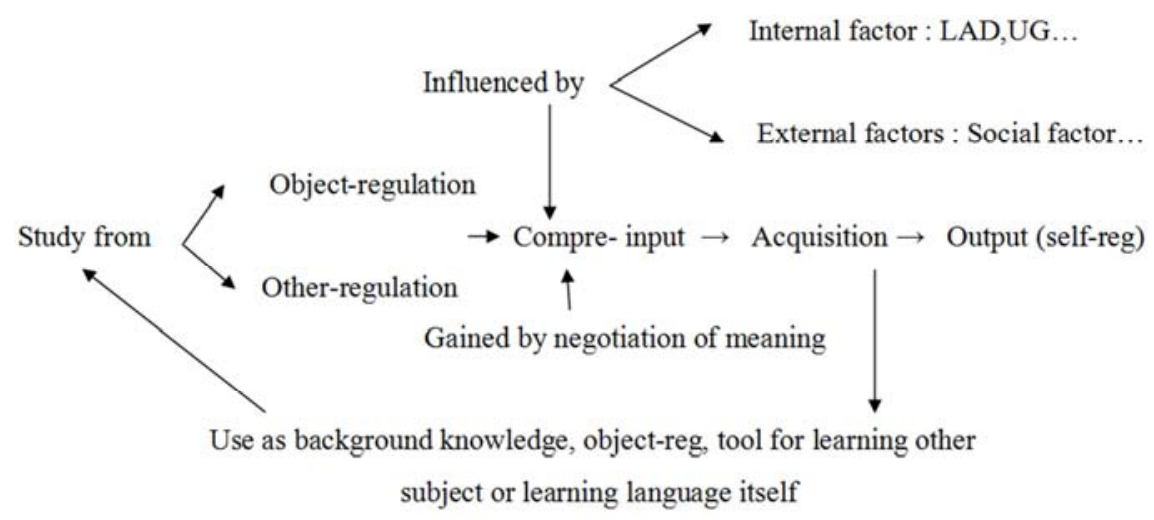

Figure 12. The Output Hypothesis of Merill Swain.

As a poem goes,

The more you study, the more you know.

The more you know, the more you forget.

The more you forget, the less you know.

The less you know, the less you forget.

The less you forget, the more you know, no-one can deny that despite of forgetting what we have studied must happen, but thank to the subconscious acquisition process, we can input knowledge in our mind after a phase of learning. As it put by Prof. Võ Văn Sen, the president of University of Social Sciences and Humanities Vietnam National University, "only if learners study a 
language, a foreign language continuously, they will gain success"

In general, the learning process can be divided into two phases: The first is the phase of inputting knowledge. This seems to be relevant to the Long-term Memory of the
Information Processing Theory. At this point, the philosophy of the Behaviorist can give a help to answer this question as "One of the logical ways is imitation and repetition through observable behaviors with the two kinds of Reinforcement [12]:

\section{Reinforcement: \\ Positive: Reward $\rightarrow$ Habit (remembering) $\rightarrow$ Knowledge \\ Negative: Punishment or Non-reward"}

Figure 13. The two kinds of Reinforcement.

At this phase, External Factors: Environment, teacher, materials are very important. "It's rare to see anyone who succeeds in learning a foreign language themselves" said by Dr. Nguyễn Đức Nghĩa, the vice president of the Vietnam National University. Moreover, correction should be concerned so strictly because language is made of patterns and structure. No-one can object to the fact that "interlingual transfer" error usually happens if the learners can not contrast the two points of grammar that have a part in common in the two languages. This leads to the situation that learners usually use knowledge of his L1 to produce the L2. After a long time this error will become habit that is too difficult to be changed.

The second phase is the phase of improving the language we have studied. With the background knowledge we have accumulated in the first phase, called schemata, learners can become more self-controlled in their learning process in which people can create new, own sentences based on gained background knowledge. Therefore, at this stage, learning is not only imitation and drilling but also creating, so internal factor - their brain (deep thinking)..... is also important. To apply this philosophy, my learners are advised to try to use their brain by deep thinking or thinking in English. Moreover, in our opinion, every other theory we have had chance to study has some points relevant to this. The phase will be analyzed on the view of the theories which has influenced on the learning process through my own learning experience.

There is an opinion that learning process is influenced by not only internal but also external factors. It seems to believe in the existence of Language Acquisition Device (LAD), and Universal Grammar (UG) of the Nativist's point of view or the IQ as Vygosky's that can be regarded as the Internal factors. The external factors also play a very important role in learning process such as: environment, teacher's direction, materials, interest, relevance, expectancy, culture, condition, outcome, attitude, linguistic rules.... [12], [14]. Moreover, according to the philosophy of the Socio-cultural Theory by Vygotsky, Halliday. Human activities and also result are defined by purpose. Three features of activity (Activity Theory) are Motivation, Action, and Condition: Motivation define activity, action decided by condition, learning activities, therefore, must be defined by learning goals. As it put by Prof. Bùi Khánh Thế, the vice president of Huflit University, "motivation plays a very importtan role in learning success". Moreover, learning is cultural development from Inter-psychological (between mind) to
Intra-Psychological (within minds): begins on social level before moving onto psychological level. That means when studying anything new, the learning process should happen in three steps to gain the mediation: From Object-Regulation to Other-Regulation to Self-Regulation. Without the SelfRegulation is like just looking at something without being sure that we can see it or not, Self-regulation is a step for learners to check themselves by doing on their own with deep thinking, the factor leading to cognition. We should base on the view: Zone of proximal Development (ZPD) of Vygotsky's philosophy to check the result of learning process [12].

\section{Conclusion}

In brief, the research has been carried out to find out the difficulties facing Vietnamese learners of foreign languages, detailed in the lecturers and students' ability and method to acquire the foreign languages, with the scope is limited in Vietnam National University HCMC, from which the strategies to develop the bilingual ability for Vietnamese in the multi-lingual communicative context have been systemized.

From data analysis of the research, the lecturers and students in Vietnam National University HCMC have good ability to acquire the foreign languages to adapt the requirement from the University for working and graduating. Moreover, some lecturers are good at a foreign language enough to go abroad for teaching and researching. Therefore, all of them have their all method to acquire their foreign languages such as English, French, ... However, they also face some difficulties in common, from which the suitable strategies have been systemized to solve their problems for developing the bilingual ability for Vietnamese in the multilingual communicative context, briefly classified as difficulties in the four skills: speaking - listening, reading and writing, as follows:

In the field of speaking and listening, based on the questionnaire result, the most difficulties facing learners is stress level identification, analyzing intonation patterns, fluency caused by translating from mother tongue into a foreign language. From the phonetic experiment, three types of English stress mistakes has been recognized as Rhythmic error, Wrong placement of stress and combination of these two types; and seven types of intonation mistakes are also summarized as rhythmic pattern, tonic syllable identification and combination in pair and in set. Therefore, English word 
stress can be recognized by the following criteria: Syllable structure characteristics, Word structure, Rhythmic pattern, and Intensity. Moreover, when pronouncing intonation, speakers must pay attention to the melody, illustrated by the pitch contour based on the intonation rules. In addition, thinking in Vietnamese and translating into a foreign language such as English in communication is a popular mistake that makes the conversation become more slowly. As a result, the useful way is practicing thinking in English by some techniques illustrated in the findings of this research. Moreover, not only intensive but also extensive listening practice plays important role in improving listening skill, from which listening and note taking is somewhat a vexed question. To solve this problem, note-taking outline, the ability of remembering, speaking, writing, are very necessary for improving listening skills. Therefore, no-one can deny that even though speaking and listening are the two separate subjects to practice, they are the two relating sides which can support each other in improving learners' ability and gaining success in communication.

In the field of reading comprehension, the difficulties facing readers are grammar and vocabularies, in which vocabularies makes the reading process slower, as well as the problem with guessing the meaning of the words from the contexts. Therefore, to guess the meaning from context, readers can base on the meaning of vocabulary items that surrounds it; the way the word is formed; background knowledge of the subject and the situation. As a result, the word relation, the structure relation, the part of speech, the word form are the important factors leading to successful guessing meaning of words based on the contexts. Beside that, the most difficulty facing learners of grammar was applying the theories to do the exercises, to real life. One of the reasons is that students do not remember the grammar rules, the theories. Therefore, learning by heart grammar structure is also necessary. In addition, when doing the reading comprehension, pay much attention to the grammar points used in the reading texts to understand grammar used in real contexts. From the importance of grammar mentioned above, teacher should teach their students a system of grammar knowledge enough in comparison with their mother tongue to avoid from negative transference mistake, for them to practice all the 4 skills before help students to practice any skills. As it put by Ms. Lê Ngọc Báu (MA), the French Lecturer in the Faculty of French Linguistics and LiteratureUniversity of Social Sciences and Humanities - VNU, Ms. Nguyễn Minh Thúy (MA), the Chinese Lecturer in the Faculty of Chinese Linguistics and Literature - University of Social Sciences and Humanities - VNU, and Mr. Võ Duy Minh (MA), the English Lecturer in the Faculty of English Linguistics and Literature - University of Social Sciences and Humanities - VNU, that they always improve their lesson plan after every semester in comparison with the mother tongue, Vietnamese to help students prevent form negative tranference mistakes. Beside that, the appropriateness of this method has been proved through my 30-year-teaching life, and has been applied with a certain success at my Center of
Foreign language, named Sa Phi Foreign Language Center Sapphire. Ltd, located in Vietnam, 57 Bùi Đình Túy Str, Ward 24, Bình Thạnh District.

In the field of academic writing, the popular problems are identifying wrong types of writing, writing ungrammatically, writing incoherently and lacking of vocabularies, as well as combination of these mistakes. To solve these problems, teachers should teach students how to develop a paragraph which consists of a topic sentences, some supporting sentences such as explanation, statistics, as well as to distinguish among the ways to develop a narrative, argumentative, cause-effect .... paragraphs/ essays. Beside that, to have enough words for a piece of writing, students should pay attention to the following ways: (1) Accumulating vocabularies from the reading texts. (2) Accumulating vocabularies from preparing for writing. (3) Accumulating vocabularies from preparing for speaking topic. (4) Making plan to cumulate vocabularies [17].

Last but not least, from the problems and solutions mentioned above, an improved teaching method has been raised as the K-W-L strategies to activate background knowledge before beginning writing or reading the text or any fields. K-W-L is a thinking-reading process, with three steps: K (What we know), W (What we want to find out, and L (What we learned and still need to learn). This procedure can help learners to access the knowledge they already have about the topic or make it available appropriately so that comprehension can occur:

The last word is that even though this research has not been able to cover all the problems facing learners of languages, these raised here should be considered as the popular and serious that must be solved to help learners be successful in studying and using a language, especially when it is not a mother tongue. Therefore, the research is always opened for adding new recognition of mistakes made by learners and their solutions, as well as any experiences from learners and teachers of languages.

\section{References}

[1] Anderson, John M.; and Ewen, Colin J. (1987). Principles of dependency phonology. Cambridge University Press.

[2] Aoyama, K. \& S. Guion. (2007). Prosody in second language acquisition. Acoustic analyses of duration and $F O$ range. In O.-S. Bohn \& M. Munro, eds. Language experience in second language speech learning. In honor of James Emil Flege, John Benjamins: 281-297.

[3] Bolinger, D. (1985). Intonation and Its Parts, Melody in Spoken English. Standford University Press.

[4] Brentari, Diane. (1998). A prosodic model of sign language phonology. Cambridge, MA: MIT Press.

[5] Nguyễn Tài Cẩn. (1997). Giáo trình lịch sủ ngũ âm tiếng Việt. Nxb Giáo dục.

[6] Chomsky N and Halle M. (1968). The sound pattern of English. New York: Harper \& Row. 
[7] Clements, George N. (1985). The geometry of phonological features. Phonology Yearbook, 2, 225-252.

[8] Clements, George N.; and Samuel J. Keyser. (1983). CV phonology: A generative theory of the syllable. Linguistic inquiry monographs (No. 9). Cambridge, MA: MIT Press. ISBN 0-262-53047-3 ISBN 0-262-03098-5.

[9] De Lacy, Paul, The Cambridge Handbook of Phonology. Cambridge University Press. ISBN 0-521-84879-2 (hbk), 2007.

[10] Trần Thị Thanh Diệu. (2015). A case study of solutions to some intonation mistakes made by Vietnamese students $A$ phonetics experimental research. International Journal of Language. Vol. 3, No. 2, 2015. pp. 52-60. ISSN: 2330-0221.

[11] Trần Thị Thanh Diệu. (2017). Some stress mistakes and solutions, a phonetic experimental research on Vietnamese students. International Journal of Language. Vol. 3, No. 2, 2017. pp. 52-60. ISSN: 2330-0221.

[12] Trần Thị Thanh Diệu. (2015). A Some Vietnamese Viewpoints upon Second Language Acquistion Theories in Language Contact Environment. International Journal of Language and Linguistics USA ISSN 2330-0221 2015; 5 (2).

[13] Trần Thị Thanh Diệu. (2016). Trying K-W-L Strategy on Teaching Reading Comprehension to Passive Students in Vietnam. International Journal of Language and Linguistics USA ISSN 2330-0221 2016; 1 (2).

[14] Trần Thị Thanh Diệu. (2012). Hiện tuợng liên ngũ tiếng Anh ở sinh viên người Việt. Tạp chí Tự điển học và Bách Khoa Thư - ISSN 1859-3135 - Sô 3 (17), tháng 5 - 2012

[15] Trần Thị Thanh Diệu. (2012). Phonetic experimental research into the acquisition of English stress through rhythm by Vietnamese students. Tạp chí Khoa học Công Nghệ Giao thông Vận tải - ĐHGTVT TP.HCM - ISSN 0866-7020 - Số 2$04 / 2012$

[16] Trần Thị Thanh Diệu. (2012). Cách xác định trọng âm tù tiếng Anh đối với sinh viên Việt Nam. Tạp chí Ngôn ngữ Đời sống - ISSN 0868-3409 - Số 6 - 06/ 2012

[17] Trần Thị Thanh Diệu. (2017). English - Japanese language and literature, some relation. LAP LAMBERT Academic Publishing - ISBN-10 3330344520. ISBN-13 978$3330344525-$ July $5^{\text {th }} 2017$

[18] Dornyei, Z. (2003). Questionnaires in Second Language Research. IEA.

[19] Duff, P, A. (2007). Case Study Research in Applied Linguistics. IEA.

[20] Nguyễn Công Đức, Nguyễn Hữu Chương. (2004). Tù vụng tiểng Việt. Tủ sách Đại học Khoa học Xã hội và Nhân văn.

[21] Fromkin V, Roadman, Collins \& Blairs. An Introduction to Language. Second Australian Edition, 1990.

[22] Fromkin V, Roadman R, Hyams N. An Introduction to Language. Nineth American Edition: Wadsworth Cengage learning, Canada, 2011.

[23] Fromkin V, Roadman R, Hyams N. An Introduction to Language. Seventh American Edition, 2003.

[24] Fry D. B. (1955). Duration and intensity as physical correlates of linguistic stress. J. Acoust. Soc. Am. 27, 765768. doi: 10.1121/1.1908022.
[25] Fry D. B. (1958). Experiments in the perception of stress. Lang Speech 1, 126-152.

[26] Fry D. B. (1965). The dependence of stress judgments on vowel formant structure. in Proceedings of the 5th International Congress of Phonetics Sciences, eds. Zwerner X., and Bethge W., Karger: Basel, pp. 306-311.

[27] Nguyễn Thiện Giáp. (2009). Các phưong pháp nghiên cứu ngôn ngũ. Nxb Giáo dục.

[28] Goldsmith, John A. (1995). "Phonological Theory" in John A. Goldsmith. The Handbook of Phonological Theory. Blackwell Handbooks in Linguistics. Blackwell Publishers.

[29] Goldsmith, John A. (1979). The aims of autosegmental phonology. In D. A. Dinnsen (Ed.), Current approaches to phonological theory. Bloomington: Indiana University Press.

[30] Griffee D. T. \& Nunan D. (1997). Classroom Teachers and Classroom research. Tokyo, Japan: The Japan Association for Language Teaching.

[31] Hadley G. (2003). Action Research in Action. Singapore: SEAMEO Regional Language Center.

[32] Cao Xuân Hạo. (2006). Tiếng Việt, mấy vấn đề Ngũ âm, Ngũ pháp, Ngũ nghĩa. Nxb Khoa học Xã hội.

[33] Hatch E and Lazaraton A, University of California. (1991). The Research Manual Design and Statistics for Applied Linguistics. Boston: Heinle \& Heinle Publishers A Division of Wadsworth, Inc Boston, Massachusetts 02116.

[34] Nguyễn Quang Hồng. (2002). Âm tiết và loại hình ngôn ngũu. Nxb Đại học Quốc gia Hà Nội.

[35] Jones D. (2002). The pronunciation of English. Cambridge University Press.

[36] Ladefoged, Peter. (2001). A Course in Phonetics (4th ed.). Boston: Heinle \& Heinle, Thomson Learning.

[37] McMahon A. (1988). An Introduction to English Phonology. Edinburgh Univiersity Press.

[38] Plonsky, L. (2015). Advancing Quantitative Methods in Second Language Research. Roughlet, Newyork and London.

[39] Richards, R, C. (1973). Error Analysis - Perspectives on Second Language acquisition. Longman.

[40] Roach, P. (1998). English Phonetics and Phonology. The Youth Press, Vietnam.

[41] SEAMEO Regional Language Center. (2003). Research Methodology Singapore: SEAMEO Regional Language Center.

[42] Spencer, A. (1991). Morphological Theory. Cambridge University Press.

[43] Stump, G, T. (2001). Inflectional Morphology - A theory of Paradigm Structure. Cambridge University Press.

[44] Lê Quang Thiêm. (2004). Nghiên cứu đối chiếu các ngôn ngũu. Nxb Đại học Quốc gia Hà Nội.

[45] Đinh Lê Thư, Nguyễn Văn Huệ. (1998). Co cấu ngũ âm tiếng Việt. Nxb Giáo dục.

[46] Đòan Thiện Thuật. (1980). Ngũ âm tiếng Việt. Nxb Đại học và Trung học chuyên nghiệp. 